\title{
DE VOORGENOMEN WIJZIGING VAN HET TARIEF DER INVOERRECHTEN GETOETST AAN DE THEORIE DER BELASTINGEN.
}

Wanneer men ieders inkomen kent en weet te onderscheiden wat voor het heden en de toekomst tot levensonderhoud in engeren en zoo ook in ruimeren zin noodig is, is men in het bezit van den best mogelijken maatstaf van elks welstand. De inkomstembelasting heeft daarom hoe langer hoe meer de aandacht der wetenschap en der wetgevers getrokken.

Die belasting heeft evenwel in de praktijk verscheidene en daaronder groote tekortkomingen, wat ernstig twijfel wekt of zij als eenige belasting - last naar draagkracht - aangenomen mag worden en of het niet beter is haar slechts een plaats in het bestaande samenstel van belastingen te geven. De voorzichtigheid dwingt reeds om niet anders dan langzaam tot de hervorming van dit samenstel over te gaan. Niet minder invloed heeft uitgeoefend de warme verdediging die aan de oude belastingen met weglating van enkele en wijziging der overige ten deel is gevallen. Mannen van groote bekwaamheid, grondleggers eener nieuwere belastingtheorie, leerden dat één belasting dwaasheid doch een stelsel naar draagkracht zeer goed mogelijk is. Wat men noodig had en grootendeels reeds bezat, was een legkaart van belastingen. De deelen zonden slechts brokstukken zijn, het is waar, doch die niet te slecht in elkaar sloten en die elkanders gebreken op bevredigende wijze vermochten op te heffen. Men was dan nog ver van het ideaal maar toch bij lange na niet zoover als wanneer tot de impôt unique werd overgegaan.

De vau ouds bestaande belastingen ziju opbrengst-, verkeersen verteringsbelastingen. Indien de eerstgenoemde een plaats in het stelsel verdienen zijn ze slechts deelen van een bijzonder soort van inkomstenbelasting. Tot de verkeersbelastingen - in den ruimen zin des woords - behoort de successiebelasting 
die ik voor zoover noodig bespreken zal. De overige verkeersbelastingen zal ik terzijde kunnen laten omdat hun betrekkelijk geringe opbrengst en meer nog het doel van dit opstel wel toelaten dat ik dit met den "Steuer-Rattenkönig" doe.

Het zijn dan vooral de verteringsbelastingen die de aandacht trekken wanueer de inkomstenbelasting als eenige last naar draagkracht onvoldoende bevredigt. Ik heb niet noodig al hun deugden en gebreken tegenover elkaar op de weegschaal te leggen. Wat ik in de eerste plaats zal onderzoeken is of zij op zichzelf of in verband met de inkomsten- en ook met de successie-belasting een druk naar draagvermogen kumnen geven. Dit onderzoek zal ons licht genoeg geven voor onze volgende overwegingen.

Die overwegingen betreffen het voornemen der Regeering om de zeer noodige verhooging der staatsinkomsten uit een ruimere opbrengst der invoerrechten, dit wil tevens zeggen uit die der verteringsbelastingen, te verkrijgen. De vraag of de Regeering ons op deu weg van het protectionisme voeren en daarmee onze welvaart bedreigen zal, laat ik geheel rusten. Het is mij te doen om een antwoord op een andere vraag, die minder dikwijls gesteld wordt, maar voorzeker niet onbelangrijk is: zal de Regeering ons dichter bij, dan wel verder van het ideaal eener eerlijke belasting-verdeeling brengen en, indien het laatste het geval is, dwingen ons dan de omstandigheden hiermede vrede te hebben?

\section{I.}

Onder de bevoegde schrijvers over de leer der belastingen, die an de verteringsbelastingen een plaats in het stelsel toewijzen, gaan in ons land en daarbuiten weinige zoover als $\mathrm{Mr}$. Pierson. Die belastingen zouden toch de kern moeten vormen, terwijl de inkomstenbelasting wel onmisbaar zoude zijn voor de verdeeling naar het draagvermogen doch slechts als aanvullingsmiddel. ")

Mr. Cort van der Linden is tegen deze woorden in verzet

1) Zie vooral de Gids van Februari 1888, bl. 314, en het Leerboek der Staathuishoudkunde, deel II, $2^{e}$ druk (1902), bl. 594. In het Gids-artikel, dat ik alleen aanhaal omdat de heer van der Linden dit bestreed, werd gesproken van de verbruiksbelastingen als kern en de andere heffingen tot aanvulling. 
gekomen. De inkomstenbelasting, saamgevoegd uit opbrengst- of ontvangst-belastingen, gevolgd door eene belasting op toevallige baten - waaronder het successierecht —, worden door hem op den voorgrond gesteld. In de derde plaats komen de verkeersbelastingen i. e. z. en eiudelijk in de vierde de verteringsbelastingen. De uitgavebelasting - in dezen geest lezen wij elders - houdt te weinig rekening met den voorna a msten factor van het draagvermogen: het inkomen. De inkomstenbelasting zal in het bijzonder de gelijkmatige belastingverdeeling kuunen geven, de uitgavebelastingen brengen den last in harmonie met. de verschillende persoonlijke omstandigheden die op het draggvermogen invloed uitoefenen; fijner werkend dan het samenstel der opbrengstbelastingen kunuen zij afwijkingen herstellen, niet de grove verdeeling der belastingen volbrengen, kunnen bovenal deze belastingen de individueele afwijkingen van de progressieve draagkracht, aan alle individuen gemeen, verevenen. ${ }^{1}$ )

Geheel anders is o. a. het oordeel van Dr. W. Vocke, een der beste Duitsche schrijvers over ons onderwerp. Wanneer deze een antwoord zoekt op de theoretische vraag hoe een belastingstelsel ingericht behoort te zijn, werpt hij de verbruiksbelastingen zoo ver mogelijk van zich af. Iets anders is het dat men die belastingen niet zal kunnen missen zoolang de zedelijke ontwikkeling nog op een te' laag peil staat voor een belasting die uitsluitend redelijke grondslagen heeft en de uitgaven, vooral tengevolge van de kosten van leger en vloot, de draagkracht voor belasting blijven overtreffen. Met het verschil in draagvermogen der burgers houden die belastingen evenwel geen rekening en hij wacht zich er dan ook wel voor om ze ergens in zijn boek deu naam "Steuern". te geven. ${ }^{2}$ )

Doch keeren wij tot Mr. Pierson terug wiens verdediging

1) De Tijdspiegel van Aug. 1888, bl. 353 en het Leerbuek der Financiën, bl. $461,458,460,446$ en 101.

2) Die Grundzüge der Finanzwissenschaft 1894; o. a. bl. 356: Eine thatsächliche, zur Zeit unentbehrliche quantitative Ergänzung ist daher die Verbrauchsauflage allerdings, aber keine grundsätzliche, unbedingt berechtigte.»

Vgl. ook het onlangs verschenen werk van B. Fuisting: Die Grundzüge der Steuerlehre, bl. 21 マv. 
der verteringsbelastingen in den geest van de meerderheid der schrijvers is, al deelen ook weinige zijn meening dat die belastingen als hoofdschotel op den disch van het uitroerend gezag geplaatst moeten worden.

"Het mag doorgaans niet aan toeval of willekeur worden toegeschreven zoo de een minder verteert dan de ander; ook bij gelijkheid van inkomen is zoodanig verschil meestal zeer gerechtvaardigd. Een koopman, bijvoorbeeld, heeft een wisselvallige zaak; op grond van zijn ondervinding acht hij het zeer mogelijk, dat hij, na jaren achtereen veel verdiend te hebben; op eens een zwaar verlies zal lijden. Is het willekeur, zoo hij, hierop rekenende, een groot deel zijner inkomsten bespart? Een arts heeft lang moeten studeeren en zich nog langer met een schraal inkomen tevreden stellen, eer zijn praktijk winstgevend werd; hij heeft misschien gedurende dien tijd ziju kapitaal herhaaldelijk moeten aanspreken. Is het ongerijmd, zoo hij thans zijn inkomen niet als $z$ uiver inkomen beschouwt en een deel afzondert om zijn kapitaal aan te vullen? - Nen ambtenaar geniet een ruime jaarwedde, maar bezit geen vermogen. Is het vreemd, indien hij jaarlijks een groot deel van zijn inkomen oplegt, ten einde bij zijn dood vrouw en kinderen verzorgd achter te laten? - Wij gelooven, dat hoe meer men bekend zou worden met de bijzonderheden van elke huishouding, vooral in den middenstand, hoe minder willekeur men bij de bepaling der verteringen in evenredigheid tot de middelen zou ontdekken. De zucht tot genot is groot genoeg, vooral in onzen tijd. Bedwingt men dien; zoo geschiedt het doorgaans om goede redenen." - "De verteringen zijn tot op zekere hoogte de vrije, de zelfstandige openbaring van den welstand, die het individu zich toekent. Zij zijn het niet volkomen; daarom kan met louter verteringsbelastingen niet worden volstaan. Maar zij ziju het in hooge wate; daarom mag men deze belastingen onmisbaar noemen." ${ }^{1}$ )

Straks kom ik op den inhoud dezer aanhalingen terug. Voorloopig houdt mij slechts een groote onvolledigheid in het betoog bezig, waardoor het hoogstens de waarde van een begin 'van bewijs heeft.

Indien de verteringen (tot op zekere hoogte) de openbaring

1) Leerboek II, bl. 594 en 595. 
van den welstand zijn en dit alleen onze aandacht verdiende; zou men al heel weinig woorden noodig hebben voor de verdediging van een samenstel van verteringsbelastingen dat alle - of, kan dit niet, verreweg de meeste - verteringen, die op draagkracht wijzen en naarmate zij dit doen, treft: Doch nu hebben wij er op te letten dat Mr. Pierson van een dergelijk samenstel, zeker te recht, niets wil weten, al is dit dan ook om allerlei bijkomende, maar toch overwegende redenen; zoo is er een regel, door hem zeer hoog gesteld, "die zich kant tegen belastingen waardoor de productiviteit van arbeid en kapitaal ernstig wordt aangetast." Best, maar nu wenschen wij toch ook te weten of een zeer beperkt getal dier belastingen, waaronder bovendien zeer onvolmaakte zullen voorkomen, eveneens tot de door hem gemaakte gevolgtrekking zou leiden. Wij ontvangen daaromtrent zelfs geen aanwijzing.

De tekortkoming in het betoog van den heer Pierson is derhalve dat de conclusie getrokken, de rekening opgemaakt wordt wanneer we nog slechts de goede eigenschap der verteringsbelastingen in abstracto keunen en dus alleen hun creditzijde is ingevuld. De debetposten komen daarna eerst te voorschijn en ze ontbreken dan ook op de balans. Geen wonder dat er nu een batig, ja een groot batig slot is en dat wij in volslage u duister verkeeren over de vraag of het saldo in werkelijkheid voor- of nadeelig is, d. i. of de groep der moge lijk e verteringsbelastingen in het geheele stelsel naar draagkracht een plaats verdient, laat staan er de kern van inoet vormen.

Niet minder stelt het Leerboek van Mr. van der Linden ons te leur. Al zeer onvoldoende wordt ons aangetoond dat een volledig geheel van verteringsbelastingen de hoofddeugd bezit die de schrijver hen toekent. Het blijft vrij wel bij het neerschrijven van eenige stellingen, doch dit is ons tot op zekere hoogte onverschillig ondat ten slotte alleen belang voor ons heeft of een uitvoerbaar samenstel aan de - desnoods zeer ratig gestelde - verwachting zal beantwoorden. Met niet genoeg te waardeeren objectiviteit worden ons, de gehreken van allerlei verteringsbelastingen voorgehouden en zoo ook de niet zelden onoverkomelijke moeielijkheden die de wetgever op zijn pad zal vinden wanneer hij het bestaande en ook naar des schrijvers oordeel zeer gebrekkige saınenstel dier belastingen herrormen 
wil. Wij krijgen dan, als we zelf een lijstje uit het boek hebben opgemaakt, een klein en bovendien gebrekkig stelletje van belastingen bijeen, doch elk spoor van bewijs dat het voldoende zou zijn voor het te bereiken doel ontbreekt.

Het idealisme van Pierson, van der Linden en zoovele andere sohrijvers, ook van hun groote voorgangers in Duitschland, is zoo groot dat zij midden in hun bewijsvoering blijven steken.

De verteringsbelasting zou naast allerlei slechte en naast vele andere goede eigenschappen blijkbaar twee zeer groute deugden bezitten. Zij zou toch het gedeelte der inkomsten, dat voor de toekomst op zij gelegd moet worden en derhalve geen draagkracht voor belasting geeft, onbelast laten. Bovendien zou zij niet evenredig zijn aan de som van alle verteringen maar alleen de minder en vooral de niet noodzakelijke uitgaven treffen. De verwachting is dus dat iemand die sparen moet of vele min of meer onvermijdelijke uitgaven te doen heeft, ontzien zal worden; dubbel ontzien wanueer zijn zorgen voor het heden en de toekomst beiden groot zijn. Komt die verwachting uit dan is voorzeker alles in het reine.

Letten wij nu vooreerst alleen op het niet belasten van hetgeen wordt opgelegd. Wij vergelijken dan met elkander twee belastingen waarvan de een aan het inkomen, de ander aan de vertering evenredig is. Om alle verwarringen te voorkomen noem ik de laatste van beide denkbeeldige belastingen verteringssombelasting. Op te merken valt dat het percentage dezer belasting hooger moet wezen dan dat der eerste omdat de maatschappelijke vertering beneden het maatschappelijk inkomen blijft.

Wanneer iemand, die tot sparen verplicht en ook in staat is, zijn plicht niet nakomt, zal zoowel de eene belasting als de andere hem naar zijn volle inkomen treffen, doch de verteringssombelasting zal met haar hooger percentage een grooter bedrag van hem vorderen. Nu zijn beide belastingen op zulk een wijze te regelen dat zij met de bloote sparplicht rekening houden, zoo niet in alle dan toch in de meest voorkomende gevallen, doch de verteringssombelasting kan het alleen voor zeer weinige harer grondslagen, kan het derhalve niet anders dan zeer gebrekkig doen. Oordeelt men dat op de spaarplicht geen acht valt te slaan, wanneer men die plicht wol kan maar niet wil 
nakomen, dan blijft toch over dat hier de verteringssombelasting, die immers hooger is dan de inkomstenbelasting, een niet gewilde en althans niet te rerdedigen straf oplegt; dit vooral wanneer het voldoende sparen het uiterste overleg en heel wat genotsonthouding eischen zou.

Meer aandacht verdient dat er personen zijn die een klein of betrekkelijk klein inkomen hebben en die, als gevoly ran hun zeer groot gezin of wat ook, ten eenenmale onmachtig zijn om voor de eigen toekomst en die van hun gezin te zorgen. Voeg bij hen allen die wel kunnen sparen maar niet wanneer zij hun kinderen een geestelijk kapitaal zullen nalaten en die - ten onrechte soms maar toch allerminst door egoïsme gedreven - een geestelijke nalatenschap boven een stoffelijke stellen. Voeg ten slotte bij hen de personen die zóó weinig kunnen sparen dat het hoogere percentage van hun vertering een gooter bedrag geeft dan het lagere van hun inkomen. Gij hebt ze dan bijeen die vrijwel het heirleger vormen van hen wier draagvermogen het geringst is en van wier inkomen zonder eenigen, souns met geringen aftrek, een te hoog percentage door de verteringssombelasting geheven zal worden

Aan de andere zijde treffen wij personen, wier dragkrachi absolunt of relatief groot is. Zij hebben een groot inkomen of, zoo het iniddelmatig is, dan zijn ze b. v. ongehuwd. Velen hunner kennen een wijze van besteden van inkomsten welke met de hoogste weeldeuitgaven op én lijn is te stellen, welke van een zeer groot draagvermogen getuigt: de kapitaliseering zonder noodzaak. Het heet dat de inkounsten- en de successiebelasting $\mathbf{k}$ u $\mathrm{n} n$ e $\mathrm{n}$ awuvullen wat zoovele meergegoeden te weinig in de opbrengst der verteringsbelastingen bijdragen. Ik kom op dit beweren terug en vooruit loopend op het bewijs dat van de aanvullende werking dier twee belastingen in ons land weinig te recht komt en onder de gegeven omstandigheden zeer moeielijk veel terecht zou kunnen komen, constateer ik dat de druk eener verteringssombelasting in den regel te laag zal zijn voor het groote, te hoog voor het geringe draagvermogen, gemiddeld minder zwaar wanneer het groote draagvermogen stijgt en het zwaarst wanneer de zorgen het meest $k$ wellen.

Te onzer beschouwing blijft over de welvarende kleinere en grootere middenklasse voor zoover deze sparen moet, $k$ an en 
wil, doch overigens haar inkomsten voor verteringen geheel noodig heeft.

Er is een medisch student, later jong arts met nog weinig praktijk, die zijn kapitaal herhaaldelijk moet aanspreken. Dit wil niets anders zeggen dan dat hij jaren lang meer verteert dan zijn inkomen bedraagt en dus ook jaren lang meer verteringssombelasting betaalt dan met een last naar draagkracht overeenkomt. Later zal hij allicht zijn best doen om het vernietigde vermogen terug te winnen. Is hij, an het eind van zijn loopbaan gekomen, in dit terugwinnen geslaagd, zoo heeft hij tevens vergoeding gekregen voor hetgeen de fiscus vroeger te veel van hem vroeg. Dan heeft echter de belasting niets voor boven een inkomstenbelasting, wel het nadeel dat hij zijn leven lang een hoog percentage moest betalen.

Slaagt hij niet in het terugwinnen - wat toch menigeen overkomt die zich verplicht ziet om inteteren gedurende zijn leerjaren, of wanneer hij zich pas in beroep of bedrijf gevestigd heeft, komt hij jong te sterven, vrouw en kinderen een verminderd of geen vermogen nalatende, dan blijft de vergoeding achterwege. In de derde plaats bestaat de kans dat de mediçus, winkelier, fabrikant of wie ook zeer gelukkig is en zijn vermogen grooter wordt dan het ooit was. In dit geval wordt aan het eind de rekening met den staat door een batig slot afgesloten.

Zoo legt de fiscus een loterij aan met verplichte deelneming. De prijzen vallen ten deel aan wie het toch reeds meeloopt in de wereld en hoe meer dit is des te grooter zal de prijs zijn. Het inleggeld - en nog viet eens ten volle - wordt terigggegeven aan wie het middelmatig goed krijgeu en zij, die in huu werkkring niet slagen, of werluwen en weezen zullen het loodje te lijden hebben.

Wat duizendmaal meer voorkomt dan het trekken van een wissel op de toekomst, is dat iemand oplegt voor de slechte jaren die voor zijn zaak of betrekking kunnen komen of zorgt voor den ouden dag, voor vrouw en kinderen wa zijn overlijden. In het ongunstigste geval moet het opgelegde later geheel verteerd worden maar dan wordt later ook in de verteringssombelasting te veel betaald in verhouding tot het werkelijke inkomen, tot het draagvermogen en om dit goed te praten moet men aannemen dat vroeger te weinig betaald was. Hoe 
dit laatste zij, het verplicht sparen heeft hier geen invloed ten goede op den druk der belasting.

Maar het kan zijn dat de slechte jaren uitblijven, dat onverwachts een erfenis ten deel valt, in 't algemeen dat iets tusschenbeiden komt waardoor het bespaarde niet aangesproken behoeft te worden. Dan krijgt de schatkist niet wat zij vroeger te weinig ontving en in dit geval zonder twijfel te weinig, al wist men dit vooruit niet. Hetzelfde geldt wanneer iemand zooveel kau sparen dat hij of zijn weduwe en kinderen, ook zonder dat een onverwacht geluk ten deel valt, wan de renten genoeg hebben, d.i. wanneer overeenkomstig de bedoeling een blijvend kapitaal ontstond, meer opgelegd werd dan strikt genomen noodig is.

Om de fraaie werking der verteringssombelasting nog duidelijker in het licht te stellen, wijs ik er op dat zij in verhouding tot het inkomen laag is in de jaren dat dit inkomen het opleggeu toelaat en hoog wauneer men moet interen. Wat zou er goeds te verwachten zijn van een belasting die zoo het beeld is der omgekeerde wereld?

Voorbeelden genoeg. Thans de geheele linie overziende blijkt ons dat een verteringssombelasting vrij aardig de kunst van het individualiseeren zou verstaan, scheidende. de personen die een groot, een middelmatig en een gering draagvermogen hebben, scheidende wie een blijvend kapitaal kan vormen en wie òf niet kan spareu òf het bespaarde later weer verteren moet, scheidende wie het mee- en wie het tegenloopt in de wereld. Maar indien we verwachten dat de uitkomst goed zal zijn, gaat het ons als iemand die vertrouwt dat zijn fotografietoestel hem een juist beeld zal geven en ontdekken moet dat de lijnen, de afscheidingen goed geteekend zijn, maar dat de tinten het donkerst zijn waar het meeste licht moest vallen, het lichtst waar de schaduw het diepst moest wezen.

De belasting zou minder sleoht werken indien het mogelijk was de oplegging uit den overvloed op voldoende wijze aanvullend te belasten. Onze plaat zou dan een egale tint hebben d. i. de belasting zou niet langer zoovele personen met hoog of betrekkelijk hoog draagvermogen ontzien, inaar toch neutrasl zijn tegenover de spaarplicht. Slechts wanneer wij aannemen dat het uitvoerbaar is de weelde-oplegging zeer zwaar te belasten en dat 
men tot dit zwaar belasten overging, zou er een ontheffingkvan druk komen voor hen die een appeltje voor den dorst moeten bewaren. Doch evenzeer voor hen die dit niet behoeven te doen, maar het toch niet zó ruim hebben, dat zij aan opleggen denken. In het bijzonder de spaarplicht ontzien is dus niet mogelijk.

De vraag komt bij ons op of de voorgaande beschouwingen bun beteekenis verlieztn wanneer er niet sprake is van een verteringssombelasting maar van verteringsbelastingen, dus: van een samenstel dat de eerste levensbehoeften niet belast, de minder noodzakelijke uitgaven middelnatig en de weelde flink.

Voor een deel is er verschil, zooals uit het volgende voorbeeld voldoende zal blijken. Wanneer iemand van zijn inkomen een gedeelte oplegt ten einde dit in later tijd te kunnen verteren strekt het inkomen van én jaar voor het levensonderhoud van meer dan twaalf maanden en wordt dientengevolge minder aan weelde uitgegeven dan wanneer het onmiddellijk geheel was verteerd. Anders dan de verteringssombelasting zal dus het samenstel der verteringsbelastingen ontzien wie sparen moet; althans wanneer hij tevens .kan en wil sparen.

Doch alleen wanneer het samenstel aan den zoo even genoemden eisch voldoet. Zal het dit werkelijk doen d.i. zal bet zwaarder drukken naarmate een grooter deel van het inkomen aan overbodiger zaken wordt uitgegeven? Ziedaar de vraag die in de tweede plaats beantwoord moet worden. Ook thans loop ik op mijn onderzoek vooruit teneinde met het eerste onderzoek gereed te kunnen komen. Het is niet mogelijk dat het minder noodzakelijke en de weelde naar behooren getroffen worden. Zelfs is er alle kans - van het tegendeel bestaat geen voorbeeld dat zij veel te licht belast zullen worden wat o. a. het gevolg moet hebben dat een jaar-inkomen bijzonder zwaar belast wordt wanneer het tot onderhoud van meer dan twaalf maanden strekt. Alleen wanneer men de belasting beperkt tot de weelde, des noods an dit woord een eenigszins ruime beteekenis hechtende, maar dan ook een buitengemeen ongelijken druk op personen van gelijk draagvermogen legt, zal de averechts werkende individualiseering vermeden worden. Een samenstel van verteringsbelastingen als het onze daarentegen zal even als, zoo niet in 
nog hooger mate dan de verteringssombelasting een te $\mathrm{zwaren}$ last te dragen geven aan allen die tot sparen verplicht zijn on die plicht even voldoende, dus zonder het vormen van een blïvend kapitaal, of onvoldoende kunnen nakomen.

De tweede deugd, die zonder eenig bewijs aan een uitroerbaar samenstel van verteringsbelastingen wordt toegeschreven staat niet alleen in betrekking tot bet al of niet sparen en moeten sparen. Evenmin als de, zorg voor de toekomst is die voor het heden steeds groot of klein wanneer het inkomen groot of klein is en ongetwigfeld is er zeker verband tusschen het draagvermogen en den aard der verteringen. Iets anders is het evenwel of nu ook de wetgever voldoende, tevens goede objecten voor de verteringsbelastingen, den juisten belastingvoet van elk hunner enz. kan vinden. Kan hij dit doen? De mij bekende schrijvers geven geen blijk dat zij ernstig over deze vraag nagedacht hebben, zoodat ik het antwoord zelf moet zoeken.

Niet alle verteringsbelastingen, bij ons of elders geheven, behoeven wij stuk voor stuk na te gaan maar toch zoovele dat een oordeel over het geheel gevormd kan worden.

Wij beginnen net de belastingen up de eerste leveusbehoeften voorbij te gaan. De rraag of b.v. een zoutaccijns als indirect hoofdgeld aanbeveling verdient kan hier onbesproken blijven. Deze accijns is voorzeker een belasting op een vertering gelegd maar de naams-overeenkomst doet die belasting nog niet behooren tot een stelsel dat individualiseerend zal moeten werken. Wat aan haar den toegang tot het samenstel ontzegt, is dat o. a. de druk grooter wordt naarmate het gezin grooter is, is dat de individualiseering in goede richting ontbreekt,

Thans valt onze aandacht op enkele zoogenaamde genotsmiddelen als: koffie, suiker, vruchten, ook rundvleeseh enz., die, wanneer men eenvoudig op den naam afgaat, tot het minder noodzakelijke, zoo niet tot de weelde behooren. De meeste dezer zaken worden bij ons en elders belast, doch het blijkt al zeer moeilijk om er én te ontdekken, die niet tot de werkelijke roedingsmiddelen behoort, althans door duizenden en tienduizenden daartoe niet gerekend wordt. ${ }^{1}$ )

1) Zoolang er nog zoovelen zijn die b.v. rundvleesch tot de eerste levensbehoeften rekenen, zou eẹn vegetariēr bij zijn kkeus der belasn 
$\mathrm{Nu}$ is het niet nogelijk om alleen het verbruik boven zekere hoeveelheid per gezinslid te belasten terwijl scheiding tusschen duurdere soorten of kwaliteiten en goedkoopere, maar tevens goede, bijna altijd van zelf uitgesloten of onuitvoerbaar is. $W_{i j}$ hebben er bovendieu op te letten dat er zoovelerlei omstandigheden zijn als leeftijd, beroep, gewoonte, wonen in de stad of buiten, kennis van en een goede wil voor een verstandige huishouding enz. die bij gelijk inkomen en draagvermogen van grooten invloed zijn op de wijze van besteding der inkomsten. Dit zou weinig beteekenen wanneer aan de legkaart der belastingen hoogstens een enkel stuk ontbrak. Het verbreekt den baud tusschen de draagkracht en den druk der belastingen nu ons lijstje der verteringsbelastingen zeer klein wordt, ja zelfs het lijstje van hun grootste voorstanders klein is. Zoo zal het toeval dier druk wel niet uitsluitend maar toch in hooge mate beheerschen en de grootte van het draagvermogen zal van geheel ondergeschikte beteekenis voor de zwaarte van den last zijn wanneer wij personen van ten naastebij gelijke, in vele gevallen zelfs van zeer ongelijke inkomens met elkander vergelijken. Bovendien zal het roorkomen dat een grooter wordend gezin meer aan het totaal dier belastingen te offeren heeft tegelijk dat de draagkracht afneemt. De belasting werkt dan individualiseerend en dit in twee opzichten te gelijk. Maar in beide opzichten in de verkeerde richting want zij wordt hooger op het oogenblik dat bepaalde behoeften toe- en de middelen waaruit die behoeften bevredigd moeten worden afnemen.

De genoemde genotsmiddelen mogen dus niet belast worden.

Wanneer wij aannemen dat sterke drank een geheel onnoodig genotsmiddel is, past de accijns toch evenmin in het stelsel en dit om de zeer eenvoudige reden dat het drankverbruik uiterst weinig verband houdt met de grootte van het inkomen en met de draagkracht. Voor zoover dit verband bestaal is wel waarschijnlijk de belasting in meerdere gevallen ougekeerd dan rechtstreeks evenredig aan het draagvermogen. Zoo zou niemand het vreemd vinden wanneer een onderzoek leerde dat zeer lage

tingobjecten het rundvleesch niet met de weeldeuitgaven op één lijn mogen stellen. Mr. Pierson - Leerboek II, bl. 598 - schijnt daarover anders to oordeelen. 
loonen het drankverbruik bevorderen 1) terwijl bovendien het drankmisbruik nooit een gunstigen, in den regel wel een ongunstigen invloed op de hoogte van het loon heeft.

Wie aan onzen gedistilleerdaccijns - zelfs voor een klein gedeelte der opbrengst - een plaats in het stelsel naar draagkracht toekent, zoo aannemelijk moeten maken dat meer sterke drank gebruikt wordt wanneer lage loonen hooger worden, de welstand toeneemt. Men maakt zich van het te geven bewijs af door te zeggen dat de staat niemand dwingt sterken drank te gebruiken, dat men het zichzelf te wijten heeft wanneer men veel accijns betaalt, enz. omdat dergelijke gezegden - in een ander verband wellicht zeer op hun plaats - geen inzicht geven in de verhouding tusschen belasting en draagkracht. Men moet voorwaar met den gedistilleerd accijns rekening houden bij het vaststellen van het stelsel der belastingen, wanneer men hem om wellicht zeer gewichtige doch niet fiscale redenen heft, maar alleen voor zoover men met allerlei andere lasten - a] of niet belastingen - rekening dient te houden.

Een belasting op het reizen in de $2^{\circ}$ en $1^{\circ}$ klasse vindt voorstanders. Laat ik van deze belasting alleen zeggen dat wię veel moet reizen meerdere malen in de verzoeking komt om in een hoogere klasse plaats te nemen dat een ander die slechts. een enkelen keer voor zijn genoegen reist, dat de belasting zich alleen tot de landsgrenzen - en dus niet wanneer het grootste bedrag wordt uitgegeven - kan uitstrekken en dat vele of lange reizen in de $3^{e}$ klasse geen mindere uitgave vorderen of van geringer draagvermogen getuigen dan weinige of korte reizen in de $2^{\mathrm{e}}$ en $1^{\mathrm{e}}$ klasse. Waarlijk, een belasting op spoorwegkaartjes zou voor het stelsel geen aanwinst zijn.

Een flinke tabaksbelasting ware voor onze handel en nijverheid zeer nadeelig. Wordt dit bezwaar tegen deze belasting niet overwegeud geacht, dan is er toch een tweede en wij hebben daarmede meer onmiddellijk te maken. Het geld, aan sigaren uitgegeven, wordt in veel minder gevallen ontnomen aan het bedrag dat voor eerste levensonderhoud bewaard moest blijven

1) Men leze o. a. wat het hoofdbestuur van den Volksbond in het orgaan van dien bond van Juni 1902 schrijft doch dat, uit gebrek aan gegevens waarover dit bestuur de beschikking kreeg, ons helaas weinig wijzer kan maken. 
dan dit wet de drankcenten het geval is en beschouwen wij de tabaksbelasting alleen uit een fiscaal oogpunt, dan zou zij voorzeker eeu der beste verteringsbelastingen zijn. Doch dit alleen indien zij niet te zeer afwijkt van een belasting die evenredig is aan de prijzen, door het publiek in de winkels besteed; anders werkt zij omgekeerd progessief en maakt het stelsel slechter in plaats van beter. Zondej twijfel is invoerrecht naar de waarde der sigaren niet on mogelijk maar wij weten dat de invoer bij ons van weinig beteekenis is tegenover het eigen fabrikaat. Het voorbeeld van de Vereenigde Staten en Rusland, die van den accijns naar de waarde zijn teruggekomen '), bevestigt dat een dergelijke accijns op te veel bezwaren stuit. $W_{i j}$ moeten het dus zonder een flinke tabaksbelasting zien te doen. ${ }^{2}$ )

Mr. van der Lindeu kent slechts twee accijnzen op goederen van weelde die hij aaubevelenswaardig acht ${ }^{3}$ ); nl. dien op gouden en zilveren werken en dieu op speelkaarten. Hij noemt er nog een te veel: den laatste. Wat verwacht men toch van een speelkaartenbelasting? Hier is een weeldeuitgave en als elke andere vitgave van dien ard kan men haar met eenige percenten der waarde belasten wanneer men oordeelt dat ieder, die veel of weinig an het overbodige besteedt, zelf aanwijst dat hij in staat is naar verhouding iets ten algemeene nutte aftestaan. Dan loont echter de belasting de kosten en moeite niet en door haar weg te laten wordt ook niet in strijd met de rechtraardigheid gehandeld omdat honderden van dergelijke weeldeuitgaven onbe-

1) Schäflle, Die Steuern II bl. 316.

2) Von Stein, Finanzwissenschaft III. bl. 352 der $5^{\text {e }}$ uitgave, oordeelde dat alleen het tabaksmonopolie een rationeele belasting kan geven en dat waarschijnlijk alle landen te eeniger tijd tot dit monopolie zullen overgaan. Indien wij het ooit doen, zal het wel over zooveel tijd zijn dat ik thans met de uitroerbaarheid geen rekening behoef te houden.

In mijn oordeel over de tabaksbelasting ben ik zeer versterkf door de lezing van: Tabak. De fiscus en volksbelang. Beschouwingen en cijfers door M. V. Snoek, 1902. Of ik tot andere gedachten zal komen wanneer de schrijrer ons iets wil mededeelen over een belasting edie den fiscus ruime baten oplevert, die billijk is naar evenredigheid van druk en die handel noch industrie in hunne welvaart belemmerts (bl: 52), meen ik te mogen twijfelen.

3) Leerboek bl. 483 . 
last moeten blijven. Of ziet men in het aanschaffen en gebruiken van kaarten een teeken van flinke dragkracht? De hooge belasting in enkele landen - in Duitschland bedraagt zij $0.50 \mathrm{M}$. voor het volledige spel - - doet dit vermoeden. Alsof de uitgaven van het leggen van een kaartje niet zoo gering zijn dat de grootte der draagkracht geheel buiten het spel blijven. Men deed in de landen waar deze belasting bestaat, beter wanneer men de jngezetenen - de armste uitgezonderd - uu en dan liet loten wie een of twee kwartjes moet offeren omdat dan een geheel willekeurige belasting niet den schijn kreeg van verstandig te zijn en hetzelfde is, goed bezien, van hee] wat verteringsbelastingen te zeggen.

Onbelast moet dus blijven verreweg het grootste gedeelte van de weelde- en de minder noodzakelijke uitgaven; zooals het ruime verbruik van allerlei genotmiddelen, de fijne sigaar en de groote reeks van kleine weeldeuitgaven welke toch te zamen een .niet onaanzienlijk deel van menig grooter of groot inkomen in beslag nemen enz. Onbelast moeten ook blijven alle uitgaven op de buitenlandsche reis; onbelast laat men gaarne de voorwerpen van wetenschap en kunst, al getuigt vooral het koopen der laatste van een in den regel groot draggvermogen, al wordt ook door de vrijstelling een zwaardere last gelegd op de schouders van hen die zich het genot of nut dier zaken moeten ontzeggen, omdat hun draagkracht geringer is.

De taak die aan een klein getal uitgavebelastingen wordt opgelegd, is veel te zwaar voor hen daar aan hun slagboom slechts een gedeelte der totale draagkracht voorbijgaat en - hierop komt het aan - een in hooge mate ongelijk deel van elks draagkracht. Ongetwijfeld zal de hoogere prijs der belaste objecten in den regel meer invloed op de keus der uitgaven hebben naarmate het draagvermogen geringer is, doch dit zal den ongelijken druk der verteringsbelastingen wel temperen, maar bij lange na niet opheffen. Alleen wanneer een helasting onevenredig zwaar drukt en dus niet in het kader past, $\mathrm{k}$ a $\mathrm{n}$ het zijn dat in het bijzonder de mindergegoeden die belasting outloopen.

De uitvoerbare verteringbelaslingen missen te zamen de individualiseerende werking. Niet geheel, het is waar, maar de verhouding van hun druk tot de draggkracht laat zooveel te wenschen over, terwijl ze niet zelden in verkeerde richting 
individialiseeren, daí voor heu geen plaats in het stelsel der belastingen, stelsel naar draagkracht, is. Kan men hen.njet in eeus, misschien nooit geheel afschaffen, dan zal dit zijn - men denke o. m. aan de drankbelasting - om overwegende maar toch bijkomende redenen. Hoe meer men hem terug kan dringen des te beter.

Aldus unoet ons oordeel ziju, wanneer. het klein getal der overblijvende voortreffelijke deelen zoude vormen van een volledig samenstel dier belastingen. Laat ons nu nog een blik te midden van hen werpen en slechts een drietal hunner: de wijn-, de paarden- en de huurwaarde-belasting naar voren brengen.

De wijnaccijns wordt ten onzent geheven naar de hoeveelbeid, niet naar de waarde. Toen in 1898 een wetsontwerp was ingediend om dien accijus te rerhoogen, bleek het dat er wel voorstanders waren van een 2waardere belasting bij den invoer op flesschen maar werd niet aanbevolen om den wijn, die hier gebotteld wordt, bij het verlaten van den kelder van den wijnkooper naar de waarde te belasten. In Frankrijk wordt met de kwaliteit eenige rekening gehouden en toch noemde LeroyBeaulieu "cet essai de proportionnalite siugulièrement grossier et incomplet". ${ }^{1}$ ) Mag men hieruit afleiden dat het ondoenlijk is om den accijns tot een redelijke belasting te maken, dan kan het niet anders of hij moet op uiterst gebrekkige wijze er toe bijdragen dat het stelsel aan zijn doel beantwoordt. ${ }^{2}$ )

Niet beter staat het met de paardenbelasting. Een progressie naar het aantal paarden van weelde vergoedt op onvolkomen wijze dat ook zij geen belasting naar de uitgave kan zijn; o. m. omdat de kosten van het paarden houden in de eene en andere gemeente aanzienlijk uit een loopen. Wat meer zegt, men heeft in dit houdeu alleen schijnbaar zulk een kenteeken van draagkracht, dat men er iets aan heeft. In ons land worden

1) Traité de la science de finances I, bl. 688 der $3^{e}$ nitgave.

2) Mr. van Houten wenschte indertijd den wijnaccijns, omdat die belasting op zulk een verkeerden grondslag steunt, afgeschaft. (de toekomst onzer financien, 1869). Schäffle daarentegen - die Steuern II, bl. 282 - zegt dat men de belasting wel goed regelen, haar zelfs progessief uaken kan wanneer men dit - door middel eener hoek- en etiketten-contrôle - wilde. De spatieering is van den. schrijver zelf en dit zegt genoeg. 
toch naast 4200 paarden, die grootendeels paarden van weelde te noemen zijn, 1000 paarden door geneeskundigen enz. en 42000 in gemengd gebruik gehouden. Hoe is het nu mogelijk om voor ruim $90 \mathrm{pCt}$. van het aantal paarden een scheiding te maken tusschen hen die vrij van pardenbelasting behooren te zijn, hen die een lichte en hen die een zware belasting moeten betalen? Men kan niet anders doen dan vour de groote meerderheid der paardenhouders luk-raak belasting te heffen, of, orn niemand over te slaan, alle paardenhouders te belasten. In de memorie tot toelichting van het ontwerp-personeele belasting dat in 1896 tot wet verheven werd, lezen wij dat de koetsiers en paarden van geneesheeren enz. belast moeten blijven omdat aan te nemen is dat zij in veel gevallen niet uitsluitend in het belang der praktijk worden gebezigd. Deze redeneering komt hierop neer: een grooter of kleiner deel der dokters en veeartsen zou rijtuig houden wanneer zij het niet reeds voor hun bedrijf noodig hadden, we nemen nu aan dat dit het geval is met alle die wel eens voor hun genoegen rijden - ofschoon het getal dan wellicht 10 of 25 maal te groot wordt - en daar we te moeilijk schifting kunnen houden slaan wij de rest ook maar aan. Men deed beter de paardenbelasting van het overgroot gedeelte der paardenhouders een soort hoofdgeld te noemen, maar dit is dan toch een uiterst gebrekkige aanvulling van de we rkelijke paardenbelasting, welke verteringsbelasting slechts een klein gedeelte der personen die zij wenscht te treffen bereiken kan.

De huurwaardebelasting heeft een goeden naam, doch geheel ten onrechte. Er zijn duizenden gevallen waarin de draagkracht een grooten invloed op de huurwaarde der woning heeft maar ook duizenden waarin die invloed ondergeschikt is of zich in de verkeerde richting uit. Denk aan de personen - zooals talrijke eigenaars, huurders van boerderijen of winkels enz. die zich geen woning kiezen en aan andere die ter wille van hun gezin of hun bedrijf in een duur huis of een dure gemeente moeten wonen. Voor de talrijke gevallen waarin een te hooge huishuur de draagkracht drukt en tegelijk een te hooge belasting zou geven - en omgekeerd - moet de wetgever tusschen beide komen maar dit is nu eens absoluut onmogelijk o. a. wanneer men terwille van zijn bedrijf boven of beneden zijn draagkracht woont, dan weer kan het slechts zeer gebrekkig ECON. 1902. 
plaats vinden; zoo zijn er ook personen die, juist omdat zij een groot gezin hebben, achteraf en daardoor goedkooper gaan wonen.

Om meer dan een reden wordt dan ook de huurwaardebelasting van het platteland als een te willekeurige belasting afgekeurd. Hoe grooter de gemeente is, des te grooter ook de kans dat de invloed van de dragkkracht op de huurwaarde niet schuil gaat onder andere invloeden op de waarde der wouing, doch in enkele steden waarin een onderzoek ingesteld is, is het willekeurige der huurwaardebelasting genoegzaam gebleken. Bijna overal is men tot de conclusie gekomen dat deze belasting, die der gemeubileerde (en verwarmde) woning of nog meer uitgebreid: "een belasting naar grondslagen" al zeer weinig heeft van een belasting naar draagvermogen. ${ }^{1}$ )

Nog één algemeene opmerking betreffende de verteringsbelastingen, om daarna onze gevolgtrekking te maken. Slechts weinige weeldeuitgaven zijn te belasten en onder degene die men overhoudt zijn er eenige die niet anders dan licht getroffen kunnen worden, omdat de grondslagen zeer onvolmaakt zijn, om - zooals dit met den wijnaccijns tevens het geval is met het buitenland handelsvrede te kunnen houden, enz. Opdat nu toch de weelde naar behooren getroffen worde, zou men de overige wel zeer zwaar moeten belasten. Aan dezen eisch is echter om drie redenen niet te voldoen. In de eerste plaats omdat de een reel besteedt aan deze, de ander aan gene weeldeuitgave en is hiervan het gevolg dat het kleine getal belastingen zeer willekeurig drukt, de willekeur zou te groot worden en te zeer in het oog vallen wanneer de percentages niet laag zijn. Opmerkenswaard is dan ook dat overal ter wereld de zuivere weeldebelastingen meerendeels tot de lagere

1) Zeer leerzaam is bijlage $\mathrm{A}$ van het rapport der Rotterdamsche Commissie van Financiën dd. 14 Nov. 1895 (Gedr. st. bl. 623 vv.) Ik verwijs ook naar de tabel van het Sociaal Weelkblad van 16 April 1892 - overgenomen in mijn artikel, Vragen des Tijds, Maart 1894 - , de Economist van Juli 1894, het Sociaal Weekblad van 15 Januari 1898 enz.

Een studie, die veel tijd zal kosten, over den druk der personeele belasting in een van onze grootere gemeenten neem ik onderhanden. 
belastingen behooren. Vindt dit tevens zijn oorzaak hierin dat de meergegoeden zoolang het roer van staat in handen hadden, ook werkt mede wat ik in de tweede plaats zal noemen. Een hooge, zelfs een middelmatige belasting op zaken van zuiver weelde zal te dikwijls ontloopen worden wanneer er kust en keur van onbelaste uitgaven is. Ten slotte: hoe hooger de belasting is, des te minder wordt de verzoeking weerstaan om den fiscus te bedriegen. Dit moet vooral af houden van een redelijke belasting op de weelde die in een klein volume een hooge waarde heeft ${ }^{1}$ ).

Gevolgtrekkingen. I. De verteringsbelastingen geven een voorrecht aan hen die van hun overvloed sparen en leggen daardoor een te zwaren druk op de overigen, hetzij deze niet sparen, hetzij zij hun spaarplicht onvoldoende of juist voldoende kunnen nakomen. Eien aanvulling door de inkomsten-en de successie-belasting heeft, op zijn minst genomen, het nadeel dat elke aanvulling en te meer een die door belastingen van geheel anderen aard geschieden moet, niet dan gebrekkig kan zijn. Wij moeten nog zien wat van deze aanvulling te maken is, maar in elk geval blijkt dat de verteriugsbelastingen een der eerste deugden, hun toegeschreven, niet bezitten, ja dat zij in plaats dier: deugd een tekortkoming hebben - het in verkeerde richting individualiseeren $m$. b. t. het al of niet moeten sparen en het opleggen uit den overvloed - en dat juist de inkomsten- en de successiebelasting te hulp dienen te komen om hen althans zoo goed mogelijk neutraal te maken. De inkomstenbelasting daarentegen kan wel met de sparplicht, ten deele ook - zooals onze rijks-inkomstenbelasting dit doet - net het werkelijk sparen uit noodzaak rekening houden.

II. De verteringsbelastingen die aan zeer matig gestelde eischen voldoen, zijn gering in aantal en van een drietal hunner, op welke wij een vluchtigen blik wierpen, kan alleen dit goeds gezegd worden, dat men elk hunner zal moeten be-

1) $\ll$ De ondervinding heeft geleerd dat.... de weelde voor $\mathrm{zware}$ belastingen onvatbaar is, daar niets lichter dan zij aan de eischen der regeering ontsnapt.» Van Voorthuysen, de Directe belastingen 1848, deel I, bl. 156.

«De voorbeelden van werkelijk uitgevoerde belastingen (van weelde artikelen) zijn betrekkelijk zeldzaam». V. d. Linden, Leerboek bl. 479. 
houden zoolang men de andere heft. Geliefd is de vergelijking van de verteringsbelasting met een net waarin de draagkracht gevangen wordt. Doch in plaats van een net heeft men hier en daar brokstukken die bij de minste aanraking nog scheuren bovendien.

Wij komen thans tot ons derde punt van onderzoek: de aanvulling der verteringsbelastingen door de inkomsten-, wellicht ook door de successie-belasting, een aanvulling die onmisbaar is omdat zoovele personen zonder eenige noodzaak een gedeelte hunner inkomsten opleggen en niet minder omdat de weeldeuitgaven gemiddeld te laag belast worden. Het spreekt van zelf dat over deze aanvulling wel iets, maar toch betrekkelijk weinig, in het algemeen is te zeggen en dat wij om die reden niet beter kunnen doen dan haar onmiddellijk in verband met ons samenstel van verteringsbelastingen te beschouwen.

Wij zijn nu verplicht te onderzoeken hoeveel de meergegoeden ten onzent aan verteringsbelastingen betalen en hoe groot hun deel in de opbrengst wel behoorde te zijn. Ons onderzoek kau geen nauwkeurige uitkomst geven en het is dan ook onnoodig dat wij in alle bijzonderheden afdalen, al zou dit nu en dau mogelijk zijn. Wij zullen bovendien tot zulke sterk sprekende cijfers komen dat het voor ons doel er niet op aankomt of de een wat te hoog en de ander wat te laag geraamd wordt: niet op de onderdeelen, op het geheel komt het hier aan.

Van de inkomens die $f 8000$. - of $f 8200$. - overtreffen, wordt in onze rijks-inkomstenbelasting een zoogenaamde extrabijdrage geheven die evenredig is an hetgeen deze inkomens hooger zijn dan het genoemde bedrag en waarvan het doel is om (eenige) vergoeding te verkrijgen voor den te lagen drak, door de verteringsbelastingen op de meestgegoeden uitgeoefend. In verband hiermede en tevens met de inrichting der regeeringsstatistiek kom $i k$ er toe om hen, die $f 8000$ of meer inkomen bezitten, meestgegoeden te noemen.

Er zijn 4938 personen ') wier vermogen minstens f 200.000

1) Tot grondslagen mijner berekeningen dienden de dienstjaren $1899 / 1900$ voor de vermogens- en de bedrijfs- en het dienstjaar 1900 voor de personeele belasting (Bescheiden b. d. geldmiddelen, stuk 25 en 26). 
bedraagt en, daar hun gezamenlijk vermogen $\mathrm{f} 2.6$ milliard uitmakkt, bezitten zij donreengenomen f 524.000 vermogen of meer dan $f 20.000$ rente. Perder zịn er 3070 personen met een arbeidsinkomen van $f 8000$ of meer. Van hen behooren er evenwel 899 tot de zeer vermogenden en o. a. hierdoor stijgt het gemiddeld inkomen der 4938 vermogenden, waaronder zij voorkomen, tot $\mathrm{f} 26.000$. Wat nu de 3070-899 personen betreft, die wel een groot arbeidsmaar geen groot vermogens-inkomen hebben, zij bezitten toch gemiddeld een zeer flink vermogen omdat in den regel groote arbeidsinkomsten met groot kapitaalbezit samenvallen ${ }^{1}$ ). Al is dan ook hun gemiddeld arbeidsinkomen niet meer dan ongeveer f 16.000 , hun totaal inkomen zal toch $\mathrm{f} 20.000$ bedragen. $\mathrm{Nu}$ zijn er nog een twee- of drieduizend personen - de statistiek laat slechts gissen toe - die minder dan f 200.000 vermogen en tevens minder dan $f 8000$ arbeidsinkomen bezitten, terwijl toch hun totaal inkomen boven de $\mathrm{f} 8000$ stijgt. Ik breng van hen 891 in rekening en verkrijg dan in het geheel 8000 personen, wier geuniddeld inkomen op (minstens) f 20.000 is te stellen. Merk op dat er nog 1000 a 2000 personen meer zijn, wier inkomen $f 8000$ te boven gaat.

In 1894 was te Rotterdam van 21 personen wier inkomens tusschen $f 18000$ en $f 22000$ liggen, de gemiddelde huurwaarde der woning $\mathrm{f} 1320$. Waarschijnlijk is dit gemiddelde thans na de herschatting hooger maar Rotterdam heeft ongetwijfeld hoogere huurwaarden dan dooreengenomen het geheele land en daarom zal een huurwaarde van f 1300 voor de huizen onzer meest gegoeden eer te veel dan te weinig zijn. Deze huurwaarde geeft een belasting vall ongeveer f 100 ; $\mathrm{nl}$. in hoofdsom daar de opceuten evenals in het algemeen de provinciale- en gemeente- belastingen hier buiten beschouwing blijven.

Er zijn 7880 personen die van 7 of meer hardsteden en wel totaal $\mathrm{f} 300.000$ belasting betalen. Rekenen wij dat $\frac{2}{3}$ van

1) Bijna 30 pCt. van hen die minstens $f 8000$ arbeidsinkomen hebben (en slechts $\frac{2}{3}$ pCt. van alle overigen die in de bedrijfsbelasting zijn aangeslagen) bezitten een vermogen van $f 200.000$ of meer en slechts $10 \mathrm{pCt}$. hunner betalt geen vermogensbelasting (tegen bijna $90 \mathrm{pCt}$. der overigen). De $60 \mathrm{pCt}$. die overblijft zal dus wel dooreen genomen meer dan f 100.000 vermogen bezitten. 
ons 8000 tal ook $\frac{2}{3}$ van dit bedrag opbrengt en dat geent der overige minder dan 6 haardsteden heeft, dan is hun gemiddelde belasting $f 30$.

De meubilairbelasting brengt niet meer dan $36 \mathrm{pCt}$. van die der huurwaarde op, maar dit mag mij er niet toe brengen om $f 36$ in rekening te lijden. $\mathrm{Zij}$ is hooger, laat het zijn $\mathrm{f} \mathbf{9 0}$.

Het aantal lieden dat 3 of meer dienstboden, ouder dan 20 jaren, houdt is 2982. Onder onze meestgegoeden zullen er daarom wel 6000 zijn die 2 dienstboden houden, enkele hunner zelfs minder en die dus dooreen nog geen $f 17$ betalen. De 2000 overige moeten gemiddeld $f 50$ offeren, rekende ik uit. Neem ik verder aan dat door hen alle mannelijke dienstboden gehouden worden en breng ik derhalve de verhoogde belasting van $4668 \times \mathrm{f} 12$ geheel te hunven laste dan mag ik de jonge dienstboden, de jagers enz. wel buiten rekening laten. De gemiddelde dieustbodenbelasting zal dan $\mathrm{f} 32$ zijn.

Indien we verder de belasting voor 4000 van de 4262 weeldepaarden en voor 2000 paarden in gemengd gebruik over onze meestgegoeden omslaan, hebben wij bij de reeds gevonden bedragen $\mathrm{f} 17$ op te tellen en komen dan tot een totaal bedrag aan personeele belasting van $\mathrm{f} 269$.

Indien onze vrienden een zevende gedeelte van den totalen wijnaccijns betalen, is de belasting voor elk hunuer $\mathrm{f} 31$, terwijl zij door $f 40$ an gedistilleerdaccijns anderhalf maal zooveel als het gemiddelde voor een gezin te offeren hebben.

Ten slotte moet nog hun aandeel worden vastgesteld in de opbrengst van de accijnzen op suiker, geslacht, zout, bier en azijn, van de invoerrechten en van de belasting op gouden en zilveren werken, alles te zamen hun aandeel in bijna $\mathrm{f} 3 \mathrm{l}$ millioen. Hun gezin, door gemiddeld nog geen drie dienstboden vergroot, zou tusschen de $f 4,0$ en $f 50$ bijdragen indien het verbruik regelmalig verdeeld was. Dit is het niet en ten einde raad boek ik $\mathrm{f} 260$ of ongeveer 6 maal zooveel. Berekend uaar de rundvleesch-accijns zou dit te weinig zijn, maar naar de suiker- en zout-accijuzen, die te zamen meer dan viermaal zooveel als de geslachtsaccijns opbrengen, is het te veel.

Ons 8000 tal brengt dan gemiddeld $\mathrm{f} 600$ aan verteringsbelastingen op.

Enkele dezer belastingen werden eenigzins uitvoerig besproken, 
niettegenstaande ik er overigens een slag in moest slaan, om te doen zien dat een weeldebelasting er grimmig genoeg kan uitzien zonder nog veel uit te richten tegen het gros der meestgegoeden. Wie bv. 12 dienstboden houdt en daaronder 3 mannelijke, betaalt $\mathrm{f} 421$, wie 6 paarden van weelde heeft, f 255 belasting, maar er ziju nog geen 3000 personen die minstens 3 dienstboden, nog geen 450 personen die minstens 3 paarden van weelde hebben. Nemen wij daarbij in aanmerking dat verreweg de zwaarste last op de jenever en de suiker, dus niet op de bijzondere verteringen der rijken is gelegd en in ' $t$ algemeen dat de wetgever, deels door de omstandigheden gedwongen, deels uit het eigen belang der eigenlijke wetgevers, het taillabel volk ruim zijn deel in de opbrengst der belastingen laat dragen, dan bevreemdt het ons niet dat de 8000 meestgegoeden, die in het bezit zijn van ongeveer de helft van het vermogen dat in de vermogensbelasting is angeslagen en van een vierde gedeelte van het inkomen dat aan de vermogens- en bedrijfsbelasting ten grondslag ligt ${ }^{1}$ ), toch niet meer dan $f 4.8$ millioen, of $\frac{1}{14}$ van het geheel, aan verteringsbelastingen te betalen hebben.

Wanneer wij thans willen nagaan welk deel de meestgegoeden in een opbrengst van ruim $\mathrm{f} 67$ millioen, thans aan verteringsbelastingen geheven, moesten bijdragen, zal de statistiek der rijks-inkomstenbelasting ons het best op weg kunnen brengen. Wij zullen een inkomstenbelasting ontwerpen die ruim

1) 4938 hunner bezitten te zamen $\mathrm{f} 2600$ millioen vermogen. Indien wij het verınogen der overige 3062 op gemiddeld $f 87000$ stellen - zie betreffende 2171 hunner bl. 655 - dan komen wij tot de helft van het verinogen - f 5738 millioen - dat in de vermogensbelasting is aangeslagen; of die $f 87000$ iets te hoog of te laag aangenomen is, is roor de uitkomst van weinig beteekenis.

Op bl. 658 vind ik bijna f 620 millioen voor het totaal inkomen dat aan onze rijks-inkomstenbelasting ten grondslag ligt. Daarvan maakt het gezamenlijk inkomen onzer meestgegoeden - 8000 $\times \mathrm{f} 20000$ of $\mathrm{f} 160$ millioen $-26 \mathrm{pCt}$. uit.

Merk op dat de rente van $\frac{1}{2} \times$ f 5738 millioen ruim $\mathrm{f} 110$ millioen bedraagt of iets meer dan $\frac{2}{3}$ van $\mathrm{f} 160$ millioen, zoodat het inkomen der meestgegoeden dooreengenomen voor $\frac{2}{3}$ uit vermogensinkomsten bestaat. Van deze kennis zal ik later gebruik maken. 
f 67 millioen opbrengt '). Niet omdat deze belasting de serteringshelastingen zou moeten vervangen, wat thans ouze aandacht niet behoeft te trekken, maar omdat de grootte van het inkomen een goede maatstaf is voor de gemiddelde belasting die personen van gelijk inkomen dienen te betalen.

De belasting door ons outworpen, zou geen verteringsbelastingen, die zoo zwaar op de mindergegoeden drukken, naast zich hebben en daarom zal zij bij een betrekkelijk laag inkomen kunnen en, neem ik aan, moetev beginnen Of zij dan altijd te innen zal zijn, gaat ons roor het doel dat wij met het ontwerpen beoogen niet aan.

In de vermogensbelasting is een vermogen van $\mathrm{f} 5738$ millioen of een rente van bijna $f 230$ millioen aangeslagen terwijl ik voor de bedrijfsbelasting, een totaal arbeidsinkomen van ten naastebij f 390 millioen berekende. Te zamen een kleine f 620 millioen op 318000 aangeslagenen. Nemen wij nu aan dat voor noodzakelijk levensonderhoud dus als vrij van belasting een algemeene aftrek van $f 400$ van elk inkomen - de duurdere en goedkoopere gemeenten, en het een en ander meer dooreengenomen - noodig is, dan houden wij een inkomen van $\mathbf{f} 490$ millioen over. Dit inkomen zou - om alleen de hoofdzaken te noemen - verhoogd moeten worden met de belastbare inkomens van den landbouw, die thans aan de bedrijfsbelasting ontsnappen, met de belastbare renten der vermogens van $f 11000$ en $f 12000$ en de belastbare arbeidsinkomsten van $f 450$ of $f 500$ tot beneden $f 650$, voor zoover deze renten en inkomens thans buiten de inkomstenbelasting vallen. Daar tegenover moet in aanmerking komen dat een belasting, die meer dan $10 \mathrm{pCt}$. van het belastbaar inkomen zal bedragen, degressief behoort te zijn voor alle inkomens die niet grooter zijn dau b. $\nabla$. $f 2000$, dat de algemeene aftrek van $f 400$ verhoogd moet worden voor de groote gezinnen en dat die degressie en ruimere aftrek een vermindering geven van het geheele bedrag waarnaar wij het belasting-percentage te berekenen hebben. Die aftrek voor groote gezinnen is - geheel of gedeeltelijk - in

1) Ik had dit bedrag met de opbrengst onzer inkomstenbelasting kunnen verhoogen maar zou dan later elks aandeel in deze belasting in mindering moeten brengen. 
rekening te brengen omdat naar verhouding weinige zeer gegoeden groote gezinnen hebben en te meer omdat de aftrek alleen bij kleinere inkomens wordt toegepast.

Waarschijnlijk zou onze einduitkomst een lager cijfer dan f 490 millioen geven, maar de berekening is al zeer weinig nauwkeurig te maken; de landbouwinkomsten zijn toch bijna niet te schatten. Waarschijnlijk lager omdat o.a. de belasting der kleine en thans belastingvrije iukomens zeer weinig zal opbrengen; zoo bevat de laagste klasse in de bedrijfsbelasting bijna $\frac{1}{5}$ der aanslagen en geeft zij toch niet eens 1 jCt. van de geheele opbrengst. Voorzichtigheidshalve neem ik een belastbaar inkomen van f 500 millioen aan, waarvàu ge middeld $13 \frac{1}{2}$ pCt. te bellen is om tot een bedrag van ruim $\mathrm{f} 67$ millioen te komen.

Gemiddeld, want een algemeene aftrek van $f 400$, vermeerderd met een zeker aantal percenten voor de groote gezinnen, doet geen belasting naar draagvermogen ontstaan. Met de spaarplicht is dan nog geen rekening gehouden. Bovendien is er e'en geleidelijke overgang tusschen het onontbeerlijkste eener- en hetgeen voor de behoeftenbevrediging van een geestelijk wezen overbodig is anderzijds, zoodat een inkomstenbelasting naar het Benthamsche stelsel bij lange na niet aan alle redelijke eischen voldoet. Om mijn berekeningen zooveel mogelijk te bekorten neem ik aan dat ons 8000 tal met hun groot en dooreengenomen voor $\frac{2}{3}$ vermogensinkomen gemiddeld 15 pCt. ${ }^{1}$ ) van huu belastbaar inkomen - geheel inkomen $\min f 400$ - zal moeten betalen.

Dit percentage, geheven van het gemiddelde inkonen van $f 20.000$, geeft een belasting van $f 2940$ en een restant van $\mathrm{f} 2340$ wanneer wij de $\mathrm{f} 600$, thans aan verteringsbelastiugen betaald, in mindering brengen.

Wij moeten echter, evenzeer als die $f 600$, de extra-bijdrage der inkomstenbelasting en, voorzoover zij in aanmerking kan kornen, de successiebelasting aan de creditzijde boeken. Die extra-bijdrage is $f 225$ voor eeu vermogen van $f 500.000$ en f 141.60 voor een bedrijfsinkomen van f 20.000 , zoodat zij

1) Zie hierover de noot op bl. 661. 
voor onze 8000 met hun groot vermogensinkomen gemiddeld $f 200$ zal bedragen. Het successie- en overgangs-recht heeft een geheel eigen functie te midden der overige belastingen en is bovendien aanvulling van deze. Wat in de zijlijnen meer dan in de rechte lijn aan recht betaald wordt, kan hier niet in aanmerking komen. Mag dit wel geschieden met de algemeene belnsting van $1.38 \mathrm{pCt}$. - successierecht - daar toch de bezitters van kleine inkomens niet te weinig verteringsbelastingen betalen en dus het recht van kleine vermogens geheven in den regel geen aanvullende belasting genoemd kan worden? Zeer zeker niet wanneer het recht even redig was aan de inkomens, die de erflaters hadden, wel, an het evenredig is aan de nalatenschappen en deze dooreengenomen naar verhouding grooter zijn naar mate die inkomens grooter waren, d. i. nu het groote inkomen gemiddeld voor $\frac{2}{3}$ en het kleine voor slechts eenige percenten uit renten bestaat. In geen geval kan echter de volle $1.38 \mathrm{pCt}$. aanvulling der verteringsbelastingen zijn, maar ik neem toch dit percentage aan, omdat ik anders met het overgangsrecht rekening moest houden.'

Daar ongeveer de helft van het vermogen, in de vermogensbelasting aangeslagen, aan ons 8000 tal behoort zal de helft, of voorzeker minder dan de helft, van de waarde der nalatenschappen - die in de laatste jaren gemiddeld f 250 millioen bedroeg uit het midden der meestgegoeden voortkomen. Een belasting van $\mathrm{f} 216$, door 8000 personen opgebracht, staat nu gelijk met; een recht van $1.38 \mathrm{pCt}$. van f 125 millioen.

In het tekort van $\mathrm{f} 2340$ wordt dus voor $\mathrm{f} 200+\mathrm{f} 216$ voorzien en nog (ruim) $9 \frac{1}{2} \mathrm{pCt}$. van de groote inkomens moet jaarlijks aan aanvulling worden opgebracht.

Het ware verkeerd wauneer men dit percentage, zelfs voor een klein gedeelte, door verhooging der successiebelasting wilde verkrijgen, omdat er onder de bezitters van groote inkomens zijn die zeer weinig vermogen hebben en dus zelfs een tiende gedeelte van hetgeen de fiscus over eeu reeks van jaren aan achterstaud te vorderen zou hebben de waarde der nalatenschap kon overtreffen.

Er blijft dus niet anders over dan een verhooging der inkomstenbelasting met $9 \frac{1}{2}$ pCt. Dit heeft twee bezwaren. Eén bezwaar is dat deze belasting dan zeer hoog wordt n.l. gemiddeld 
$13 \frac{1}{4}$ pCt. ${ }^{1}$ ). Wanneer wij onze 8000 in klassen naar hun mkomsten en verder naar de bronnen hunuer inkornsten splitsten, zou dit percentage voor de eene groep lager, voor de andere hooger blijken te zijn; o. m. omdat voor inkomens vau twee of vijfmaal f 20000 de druk der verteringsbelastingen minder dan twee of vijfmaal $f 600$ is en de progressie der bestaande extra-bijdrage hiertegen niet opweegt. Het percentage van $13 \frac{1}{4}$ is dus niet het maximum.

Fen inkomstenbelasting, waarvan het maxiwum-percentage zoo hoog is, heeft het groote nadeel dat zij het misleiden van den fiscus zeer in de hand zou werken. Het is waar dat bij het afschaffen der verteringsbelastingen dit percentage nog hooger zou zijn. Indien toch de f 600 vervalt, die de meestgegoeden gemiddeld aan deze belastingen opbrengen, wordt het gemiddeld percentage van $13 \frac{1}{4}$ met 3 verhoogd en indien het maximum bij het behoud dier belastingen 15 of 17 zou moeten zijn, zal

1) Onze meestgegoeden betalen dan dooreengenomen jaarlijks 3 pCt. van hun inkomen aan verteringsbelastingen, $1_{1 \%}^{2} \mathrm{pCt}$. na hun overlijden geïnd en $131 \mathrm{pCt}$. aan inkomstenbelasting, de bestaande extra-bijdrage en de nieuwe aanvulling daaronder begrepen. Door een belasting van $\pm 17 ! \mathrm{pCt}$. van hun inkomen dragen zij derhalve naar mijn berekening hun gerecht deel in een bedrag van f 83 millioen (aan verteringsbelastingen, inkomstenbelasting - na aftrek van de belasting der naamlooze vennootschappen enz. - en een successierecht van 1.38 pCt.)

Dit bedrag van $f 83$ millioen is ougeveer acht maal zoo groot als de opbrengst onzer inkomstenbelasting, wanneer wij van deze ook de extra-bijdrage aftrekken. Hun inkomen draagt thans in de opbrengst der inkomstenbelasting dooreengenomen $2.8 \mathrm{pCt}$. bij - d. i. zonder de extra-bijdrage - hetgeen met 8 vermenigvuldigd zou geven: $22 \frac{1}{\mathrm{pC}} \mathrm{pt}$. Het verschil tusschen dit percentage en dat van $17 \frac{1}{2}$ vindt zijn hoofdoorzaak daarin dat de vermogensinkomsten ruim $1 ! 200$ zwaar als de arbeidsinkomsten zijn belast, terwijl ik het gemiddeld percentage van $13 \frac{1}{2}$, noodig om een opbrengst van ruim $f 67$ te verkrijgen, voor de groote inkomens, welke gemiddeld voor $\frac{2}{3}$ uit renten bestaan, niet hooger dan tot 15 voor het gemiddeld groot inkomen bracht. Van een te forsch de groote inkomens te willen aanpakken heb ik dan ook geen blijk gegeven, al zou het ongetwijfeld verkeerd geweest zijn wanneer ik voor mijn anvullende belasting het verinogen zooveel zwaarder getroffen had dan de arbeidsinkomsten als onze inkomstenbelasting doet. 
het zonder deze belastingen wellicht 17 of 19 worden. $\left.{ }^{1}\right)$ Maar dit meerdere, gevoegd bij een reeds zoo hoog percentage, zou het ontduiken van belasting niet zoodanig doen toenemen dat de groote willekeur, de kosten, de belemmeringen enz. der verteringsbelastingen er tegen op wegen. Alleen door de aanvulling achterwege te laten of tot een paskwil te maken kan men een inkomstenbelasting met een hoog maximum-percentage voorkomen. Men behoudt dan eenige honderdduizenden die anders aan de schatkist door nog meer geknoei bij de aangiften ontgaan, maar schenkt dan ook een aanzienlịk bedrag aan de meergegoeden dat, naar onze ruwe berekening, voor ous 8000 tal $8000 \times \mathrm{f} 1900$ of ruim $\mathrm{f} 15$ millioen's jaars bed raagt en in het geheel wel f 20 millioen omdat er nog zooveel duizenden andere personen zijn die een betrekkelijk groot inkomen hebben en evenzeer te licht in de verteringsbelastingen zijn aangeslagen.

Een schijnbaar uitstekend argument van de voorstanders dier belastingen, dat deze belastingen een inkoinstenbelasting met hoog maximum-percentage onnoodig maken, heeft dus geen warde van eenige beteekenis. Wie het beginsel, dat aan het belastingstelsel ter grondslag moet liggen, aanvaardt, kan een hoog percentage ontloopen, noch wanneer ons samenstel van verteringsbelastingen blijft zoo als het is, noch ook - daartoe heeft mijn lang hetoog tevens gediend - wanneer het zoo goed gemaakt is als wij in staat zijn het te maken.

Er is een tweede bezwaar. De anvullende belasting zal, zoo vonden wij $9 \frac{1}{2}$ pCt. van het inkomen van $f 20000$ of te zamen met de bestaande extra-bijdrage ongeveer $10 \frac{1}{2}$ pCt. bedragen en voor de groote inkomens heel wat meer. Dit aanzienlijk percentage zal voor velen, die eenvoudig leven en zeer weinig verteringsbelasting betalen, te laag en zoo ook voor anderen eenige percenten van hun inkomen te hoog zijn. De aanvulling zal dus zeer onrechtvaardig verdeeld worden en uu kan men o. a. wel het percentage nog iets verhoogen en dan in mindering brengen wat ieder aan personeele belasting betaalt, maar hetzelfde is niet te doen voor de indirecte

1) Het verschil zal wel minder dan 2 pCt. bedragen daar niet aan te nemen is dat van de zeer groote inkomens gemiddeld $2 \mathrm{pCt}$. aan verteringsbelastingen betaald wordt. 
belastingen en in het algemeen zal het onmogelijk zijn om de verteringsbelastingen op goede wijze door een inkomsten- en nog minder door een successiebelasting an te vullen. Aan het groote bezwaar dat de eene gegoede voor den ander zal moeten betalen is niet te ontkomen dan door het aanvullend percentage laag te stellen en dus den mindergegoede het kind der rekening te doen zija.

Aan de conclusiën van bl. 653 is derhalve toe te voegen: III. De aanvulling der verteringsbelastingen voor hetgeen de meer- en meestgegoeden te zamen in de opbrengst dier belastingen te weinig deelen, kan niet anders geschieden dan door een zó́ onbillijke verdeeling dier aanvulling over deze persouen, dat haar invoering tot een behoorlijk peil op zeer groote bezwaren stuit.

IV. Wanneer men de meergegoeden niet wil ontzien ten koste der mingegoeden is naast de verteringsbelastingen toch een inkomstenbelasting met een hoog maximum-percentage te heffen. Nauwer saamgevat is ons oordeel: de verteringsbelastingen ontzien de sparplicht niet, werken niet individualiseerend, leggen een hoogst willekeurigen druk op en eischen een aanvullende belasting, die eveneens zeer willekeurig zal belasten en die te zamen met de inkomstenbelasting, aan welke zij wordt toegevoegd, een maximum-percentage zal heffen dat weinig minder ontduikingen zal doen ontstaan dan door een inkomstenbelasting, die de bestaande en de verteringsbelastingen zou vervangen, werd uitgelokt.

Tenzij men geen anderen uitweg heeft om een zeer noodige verhooging van inkomsten te verkrijgen, mag in geen geval de opbrengst der verteringsbelastingen verhoogd worden. Mocht het evenwel zijn dat in het samenstel dier belastingen gebreken zijn weg te nemen door enkele weeldezaken te belasten of zwaarder te belasten, dan zou de meerdere opbrengst in de eerste plaats moeten strekken om den druk der slechtste verteringsbelastingen te verminderen en dit vooral wanneer er onder deze zijn die zeec onrechtvaardig drukken en de totale opbrengst der verteringbelastingen bijna $7 \mathrm{maal} \mathrm{zoogroot}$ is als die der zuivere inkomstenbelasting. 
II.

Ik kan thans kort zijn bij de beantwoording der volgende vragen die in nauw verband met elkander staan: tot welke belastingpolitiek zijn wij voor de naaste toekomst aangewezen en hoe hebben wij over het voornemen der Regeering te oordeelen? Bij die beantwoording is in anmerking te nemen dat de inkomsten van den staat verhoogd moeten worden en dat de sociale wetgeving meer nut zal, althans kan doen naarmate de belastingen meer opleveren. Niet alleen op de gebreken van het samenstel onzer belastingen moet derhalve het oog gevestigd worden.

Noodig is dan zoowel vermeerdering van inkomsten als opheffing van de bevoorrechting der meergegoeden en — wat niet hetzelfde is omdat de belastingen ten eenenmale te zwaar op de mingegoeden drukken en tevens te ongelijk op personen van eenzelfde draagvermogen - afschaffing of drukvermindering van eenige belastingen, te beginnen bij de slechtste. In de plaats van dit laatste is niet te stellen onmiddellijke afschaffing van alle verteringsbelastingen: met den gedistilleerdaccijns zou het vooreerst niet kunnen; in vele economische verhoudingen werd te plotseling een diepe greep gedaan; het schort niet alleen bij deze belastingen, daar ook het samenstel der verkeersbelastingen dringend herziening eischt; zoo is er meer.

De opheffing van belastingprivilegiën zal de inkomsten van den staat kunnen vergrooten of (en) een vergoeding geven voor het verlies dat van de afschaffing of de verlaging van eenige belastingen het gevolg is. Zoo is de wetgever aan den schuldeischer gelijk die slechts rekeningen uit te schrijven en te verzenden heeft om aan geld te komer. Uit mijn berekeningen blijkt dat ik een aanvullende belasting van een $f 20$ millioen noodig acht om een einde te maken aan de bevoorrechting die alleen de verteringsbelastingen aan de meergegoeden geven en een nauwkeuriger becijfering zou, het is waar, een lagere uitkomst kunnen geven, maar in geen geval zooveel dat geen aanzienlijke opbrengst te verwachten is.

Niet alleen dat verhooging van de progressie der inkomstenbelasting aan privilegiën een einde zal maken, maar evenzeer zal dit het geval-zijn, naar ik meen, met het progressief 
maken der successiebelasting en het invoeren van een belasting op enkele goederen in de doode hand. Wij moeten daarom vragen wat op den voorgrond dient te staan: wijziging onzer rijks-inkomstenbelasting of iets anders waardoor ook voorrechten worden opgeheven? Mij komt het voor dat die wijziging in de eerste plaats aanbeveling verdient, al ware het alleen omdat zij het veelzijdigst voorrechten te niet zal doen; de nieuwe en hoogst billijke druk zal dan toch niet alleen op de grootere vermogensinkomsten maar ook op de grootere arbeidsinkomsten gelegd worden. In den kortsten tijd wordt dan tevens het grootste bedrag verkregen.

Vragen wij nu verder wat met de nieuwe inkomsten gedaan moet worden: de middelen versterken of slechte belastingen er tegenover afschaffen, dan zal ons antwoord, het spreekt van zelf, afhangen van het nut dat bepaalde, kostbare maatregelen, in het algemeen belang te nemen, kunuen stichten, van het bedrag dat de inkomstenbelasting meer zal opbrengen en van het verschillend oordeel dat over allerlei slechte belastingen te vellen is. In de eerste plaats is er zeker voor te zorgen dat geen tekorteu ontstaan, in de tweede plaats is er op te letten dat de minister van financiën niet over alle krachten der wetgevende macht beschikken kan en mag totdat ons samenstel van belasting aan redelijke eischen voldoet. Versterking der middelen zal daarom op den voorgrond moeten staan. Elke stap dien wij verder doen op een terrein, dat nog onnauwkeurig bekend is, kan ons leeren waar wij den voet verder te zetten hebben, inits wij slechts weten wat het einddoel is. Dit einddoel moet ongetwijfeld zijn het afschaffen, c. q. verlagen, der slechte belastingen en verhoogen of invoeren van andere belastingen, waardoor bijdragen van hen, die tot dusver ten onrechte laag of niet belast zijn, verkregen worden.

Het zal verstandig zijn om zich verloopig - op.den duur is het oumogelijk hoe wij het draaien en wenden, tenzij er een veel gunstiger verhouding komt tusschen maatschappelijk inkomen en de behoeften van den staat - te houden aan het waarschuwend woord van zoovele schrijvers en de inkomstenbelasting niet hoog op te voeren. Men zal dan groote ontduikingen voorkomen en het verzet der bevoorrechten breken, 
wier invloed op den gang der zaken zoo groot is en die, als de geschiedenis onzer belastingwetgeving op elke bladzijde leert, bewust of onbewust hun krachten aanwenden om steeds een deel hunner privilegiën in veiligheid te houden.

Van de groote vermogens wordt thans een belasting, waaronder extra-bijdrage, geheven die bij een renteberekening naar 4 pCt. bijna 5 pCt. van het inkomen bedraagt, terwijl de bedrijfsbelasting in het uiterste geval $3 \frac{2}{10}$ pCt. is. Een nieuwe anvulling van 4 pCt. als gemiddeld voor ons 8000 tal en wellicht van 5 pCt. als maximum zal daarom geen overwegend bezwaar geven. Het is waar dat dan de lasten, verhoogd door die welke de provincie en de gemeente opleggen niet gering zullen zijn voor de meestgegoeden, maar men ontkomt dit niet tenzij men de zwakkeren een nog veel hooger percentage op den hals schuift. Omdat de verbeteringsbelastingen zoo moeielijk zijn naterekenen wordt dit meestal vergeten, maar wordt de werkelijkheid niet beter.

Deze aanvulling van slechts 4 pCt. in plaats van de $9 \frac{1}{2}$, die wij noodig achtten, heeft bovendien het voordeel dat zij niet te slecht bij de verbeteringsbelastingen zal aansluiten. Wij weten toch dat de meestgegoeden thans moeilijk naar behooren te treffen zijn, omdat de een voor den ander zal betalen wanneer men naast de verteringsbelastingen een zoo hooge aanvulling heft als dooreen genomen billijk zou zijn. Van den bezitter van een inkomen van $f 20000$ zal bij een aanvallende belasting van $4 \mathrm{pCt}$. $\mathrm{f} 800$ geheven worden waardoor nog een te kort van gemiddeld f 1100 overblijft en alleen wanneer hij niet $f 600$ maar meer dan $f 6^{2} 00+f 1100$ aan verteringsbelastingen betaalt wordt van hem te veel gevergd. ${ }^{1}$ )

De gemiddelde aanvulling van $4 \mathrm{pCt}$. van een totaal inkomen van $\mathrm{f} 8000 \times 20000$ geeft een opbrengst van $\mathrm{f} 6,4$, millioen. Begint nu deze aanvulling, die progressief moet zijn en - ik wijs er wellicht ten overvloede op - niet dient om de be-

1) Indien de opbrengst der anvulling dient of tevens dient om den totalen druk der verteringsbelastingen te kunnen verlagen en dus om vooral de mindergegoeden te ontheffen, neemt percentsgewijs de ruim $\mathrm{f} 67$ millioen aan verteringsbelastingen sterker af dan de $f 600$, die de meestgegoeden thans gemiddeld opbrengen. De aanvullende belasting behoort dan iets beneden de $9 \frac{1}{2}$ pCt. blijven. 
stande inkomstenbelasting op zich zelf meer progressief te maken, bij b.v. $f 2000$ of $f 3000$ inkomen al naarmate een onderzoek leert dat bij inkomens boven $f 2000$ of boven $f 3000$ de druk der verteringsbelastingen op beteekenisvolle wijze begint te dalen, dan wordt waarschijnlijk een totale opbrengst van een $f 8$ millioen verkregen. Met dit bedrag kan men derhalve de uitkomst onzer inkomstenbelasting verhoogen zonder dat het maximum-percentage te zeer wordt opgedreven, zonder onrechtraardigheid van eenige beteekenis tegenover de meergegoeden die toevallig veel uitgeven op zulk een wijze dat zij door de verteringsbelastingen flink getroffen worden, terwijl naar onze ruwe berekening de meestgegoeden gemiddeld bijna $60 \mathrm{pCt}$. van het privilegie, dat zij genieten, zullen behouden.

Met de wijziging der inkomstenbelasting, ten einde haar althans iets beter aanvulling der verteringsbelastingen te doen zijn, kan een herziening dier belasting op zich zelf gepaard gaan. De arbeid van Mr. Pierson was indertijd zoo moeilijk omdat deze ninister privilegiën aantastte en zijn wetten geen voorgangsters hadden. Dit wordt door vele, die den staf over die wetten breken, vergeten. Thans zal een minister, die de hand aan heu slaat, wel een moeilijke maar geen te zware taak op zich nemen.

Tengevolge eener algemeene herziening kan de opbrengst met meer dan $f 8$ millioen toenemen, ook wanneer aftrek voor kinderen wordt gegeven. $\mathrm{Er}$ is geen voldoende reden om de landbouwwinsten - die van zelf niet of licht belast zullen worden wanneer zij gering zijn - vrij te laten. Evenmin is te verdedigen dat de grootere arbeidsinkomsten zóóveel lager belast worden dan de grootere vermogensinkomsten als thans geschiedt; dat van het "Nutzkapital" slechts een gedeelte in de vermogensbelasting is angeslagen; dat zonder uitzondering een gedeelte van elk pensioen onbelast is enz. enz. Door het opheffen van zoovele privilegiën in de inkomstenbelasting zal voorzeker tegenover enkele eenig onrecht geschieden maar men mag niet over het hoofd zien dat, wanneer de opbrengst dier belasting niet wordt verhoogd, op een andere wijze een uieuwe last te leggen is, die in zooveel hooger mate onrechtvaardig zal drukken en die het vooral op de zwakken voorzien zal hebhen. De zachtheid der inkorstenbelasting is geen deugd, ECoN. 1902. 
al is zij an een eerstelinge te vergeven, want het is uit een andermans leer dat die belasting riemen snijdt.

De Regeering heeft zich neergezet om een wet tot verhooging van de opbrengst der invoerrechten voor te bereides. Was nu het voornemen om uitsluitend weelde-uitgaven te belasten of zwaarder te belasten, ik zou waarschijulijk gezwegen hebben. Het is waar dat dan weer een zeer ongelijke druk op de meergegoeden werd gelegd en waarschijnlijk ook een nieuwe last op vele mindergegoeden, maar de verhoogde druk $k$ on dan toch voornamelijk hen treffen die thans te weinig betalen, de uitkomst $\mathrm{k}$ o $\mathrm{n}$ zijn dat het samenstel der verteringsbelastingen er minder gebrekkig door werd. De tijd tot oordeelen zou nog niet ten volle aangebroken zijn.

Intusschen is voldoende gebleken dat de Regeering niet alleen naar weeldeuitgaven zoekt. Zij weet toch wel dat dan de opbrengst, en dit te meer wanneer de belasting alleen bij den invoer ge-heven wordt, gering zal zijn. Zij zou bovendien het bijzonder doel, met de herziening beoogd, niet voor zich hebben gehouden en het eenige licht, voor ons ontstoken, ware niet geweest dat het gewijzigde tarief wellicht een nieuwen druk op de mindergegoeden zal leggen.

Wij weten dus met genoegzame zekerheid waar het heen zal gaan: nieuwe last ook voor den zoo zwaar beladen kleinen man. Verder tasten wij nog in het blinde rond. Zal die nieuwe last, up zich zelf beschouwd, progressief, proportioneel of weer omgekeerd progressief gelegd worden? Ik heb geen reden om optimistisch gestemd te zijn maar dit bewijst niets en ik houd inij dus aan het minimum dat wij zoo goed als zeker weten.

Zonder eenigen twijfel zijn op het voornemen der Regeering twee anmerkingen te maken. De eerste is deze. Had de Regeering naar nieuwe inkomsten gezocht door aan de meergegoeden een gedeclte van hun belasting-privilegiën te ontnemen dan zou zij twee goede dingen tegelijk hebben gedaan. Het eene, verschaffen van nieuwe fondsen, zal ook thans worden verkregen; van het andere, billijker verdeeling der lasten, kount niets of, indien het mocht zijn dat de nieuwe of verhoogde rechten in den regel meer op de gegoeden drukken, komt toch te weinig terecht. Geen Regeering kan zich dekken door te wijzen op het 
slechte voorbeeld dat te vele harer voorgangsters gegeven hebben.

De tweede aanmerking is dat de tariefsherziening ons verder van een goed belastingstelsel zal brengen daar niet eenvoudig slechtere verteriugsbelastingen door betere vervangen zullen worden maar hun totale opbrengst een verhooging zal ondergaan. Wanneer een gebouw - het gebouw van ons geheel samenstel van belastingen - te klein is en tevens een zijner vleugels ingekort moet worden, kan het zeer goed zijı dat men niet te gelijk beide eischen rermag te bevredigen. Men bouwe dan b.v. aan den niet te langen vleugel zooveel aan dat de ruimte voldoende is en zette dien bouw een volgend jaar voort, waarna de andere vleugel ingekort kan worden, maar het kan nooit een wijze politiek ziju die begint met dezen vleugel nog meer te verlengen. Men schuift dan een dubbel zware taak op de schouders van den opvolger en deze zal wel over een drieunaal grootere kracht de beschikking moeten hebben wanueer hij bet werk moet doen waarvoor thans de krachten ontoereikend worden geacht

Ous samenstel van belastingen zal door de Regeering slechter in plaats van beter gemaakt worden, de vooruitgang sedert een halve eeuw zal niet in stilstand maar in achteruitgang overgaan. Alle twijfel is hier uitgesloten, al moge het aangekondigde ontwerp ook beter zijn dan ik mij kan voorstellen.

De Regeering heeft iets tot rechtvaardiging van haar plan aangevoerd. Indien de minvermogende, zoo liet zij zich uit, door de herziening van het tarief gedrukt wordt, zal biermede rekening worden gehouden bij het bepalen zijner bijdrage in de verplichte ziekte- en invaliditeits-verzekering.

De voor- en nadeelen der schatkist kunneu op deze wijze voorzeker tegen elkaar opwegen. Maar zal het bij den onregelmatigen druk die de rerteringsbelastingen uitoefenen en in elk geval bij den geheel anderen grondslag van deze belastingen en van de verzekering, zal het zeker zijn dat de vooren nadeelen voor elk individu genoegzaam tegen elkaar opwegen en weegt dit punt niet zwaar, waar het personen betreft die kleine inkounens hebben en in den regel nu reeds te zwaar belast zijn? 1) Het antwoord ligt voor de hand.

1) Zic de Economist van October 1901, bl. 796. 
$\mathrm{Er}$ is meer. In de eerste plaats dat het goede voornem̌en der Regeering hoogstens zou kunnen bewerkstelligen dat de mindergegoedeu dooreengenomen niet zwaarder gedrukt worden dan thans. Van den kostbaren tijd onzer wetgevende macht gaat dan toch een gedeelte half verioren omdat mell - ik treed in herhaling - het versterkẹn der middelen ook kon verkrijgen door wegneming van privilegiën, terwijl bovendien de beloofde compensatie in geenen deele wegneemt dat met het samenstel der belastingen wordt geknoeid, dat het na enkele met veel moeite en telkens na lang wachten verkregen verbeteringen, weer achteruit wordt gezet.

Ten slotte. Zooals de Regeering zich verdedigde had zij slechts mogen spreken wanneer geen rekening met den mindergegoede te vereffenen viel. Deze, die op een open post in zijn boek kan wijzen, heeft alle recht om te antwoorden: Gij verwacht van uw gewijzigd tarief van invoerrechten een overschot, nadat in allerlei nieuwe behoeften is voorzien en wilt nu dit overschot aanwenden ten onzen behoeve, waarvoor gij $\mathrm{u}$ eerst bij ons in nieuwe schuld steekt. Een zelfde, allicht grooter overschot kunt gij verkrijgen door $u$ uitsluitend tot hen te wenden, aan wie overoude privilegiën toch eens afgenomen dienen te worden. Geeft gij dit oversehot ten onze behoeve nit, dan ontrangen wij nog niets te veel, zoolang de privilegiën niet geheel vervallen zijn. Geen enkele goede reden kan er voor u wezen om vóór alles een oude schuld tegenover ons te vergrooten. ${ }^{1}$ )

Wij wenschen vooruitgang, geen stilstand, allerminst achteruitgang in het samenstel onzer belastingen, opdat het te eeniger tijd een stelsel worde. Wij wenschen versterking der middelen maar dit dient in de eerste plaats verkregen te worden door ben, die hun gerecht deel niet betalen, zwaarder te belasten. Het roornemen der Regeering is gewogen en te licht bevonden.

Utrecht, Juli 1902. Dr. W. H. DenIER vaN DER Gon.

1.) Hoe anders Schäffle - Die Steuern deel II, bl. 423 - welke voorstander der verteringsbelastingen niet voorbij ziet dat het volk (in Duitschland) een te groot deel van de verbruiksbelastingen opbrengt en daarom een deel der bestaande opbrengst voor het reservefonds der rijks-verzekeringsbank wenscht aangewend te zien. Zoo schreef hij reeds in 1880 in zijn Steuerpolitik en schreef het in 1897 na. 